\title{
Serious games in theology
}

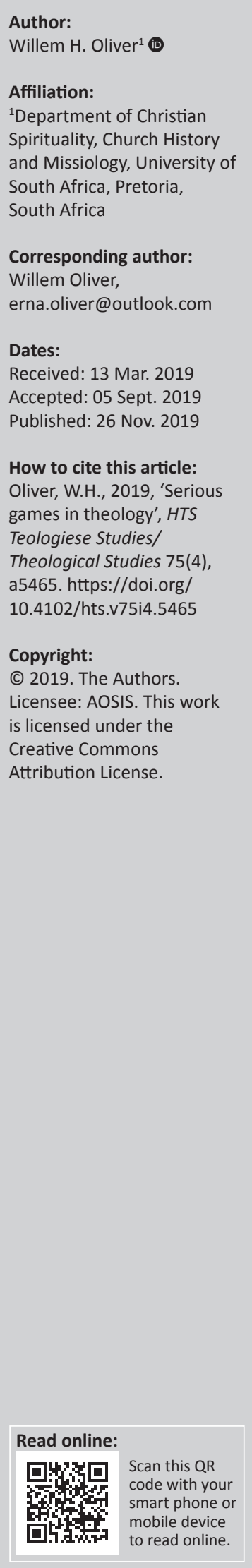

\begin{abstract}
In South Africa, the implementation of serious games and gamification (collectively referred to as gaming) in the design of curricula, being presented in schools and institutions of higher education, is mostly a novelty. As we are (should be) in a transitional phase with education, especially on two levels, namely, with the decolonisation of education and preparing education for the Fourth Industrial Revolution, it would be fitting and high time to fully implement gaming into the curricula. This article takes a look at the implementation of a serious game on an undergraduate level at a residential university. It focuses in a pragmatic way on applying the serious game on biblical languages - Greek, Hebrew and Latin - proposing that they should be presented to the student as paper behind the glass.
\end{abstract}

Keywords: serious games; gamification; online; paper behind the glass; decolonised education; Fourth Industrial Revolution.

\section{Introduction}

Before discussing the implementation of serious games in theology, a few definitions are given to introduce the concepts being used in this essay. Firstly, the two concepts are 'paper behind the glass' and 'online course': when a course or module is just 'dumped' as is on the Internet, that is not a real online course, but rather 'paper behind the glass' (Ncube, Dube \& Ngulube 2014:360). Sometimes, it serves a purpose to electronically supply a full course to students, especially in the current educational era that should already be 'paperless' (defined below). It is also most useful for subjects that really need much explication and explanation, like the three biblical languages, Greek, Hebrew and Latin. A 'real online course' is much different: the student is online supplied with a table of contents and just enough information to get started and to look up the rest of the information on the Internet (cf. Caplan \& Graham 2004:178). The course is not only a summary of the study guide, but also is developed from scratch, where the content is not set but open (Davis 2004:98). When directing a student to the Internet, the educator should give them solid guidelines in order for them to be well informed on how to critically distinguish between 'good' and 'bad' information or sites, and between sites that can act as sources for academic information and 'casual sites' that just supply opinions or loose information. This will empower the students to start with research soon in their academic career and will optimistically act as motivation for them to become lifelong learners. ${ }^{1}$

Secondly, the difference between serious games and gamification: the term 'serious games' (as used by Richter, Raban \& Rafaeli 2015:22; cf. also Michael \& Chen 2006) was first called 'digital game-based learning' by Prensky in 2001 and defined as 'any marriage of educational content and computer games' (Prensky 2001:145). Closer defined, serious games are 'games whose primary objective is NOT fun or entertainment, rather learning or practicing a skill' (Gamelearn 2017). This does not mean that fun and entertainment are excluded, but that they form part of the secondary objectives of these games, which are educational games played on electronic devices. Gamification, coined by Pelling in 2002, can be defined as 'the use of game elements in a non-gaming context' (Deterding 2011; cf. also Zichermann \& Cunningham 2011:xiv). Within the environment of higher education, this can translate into an activity designed for students - inside or outside the classroom - containing game-like elements, which may even exclude an electronic device. ${ }^{2}$ Abroad the utilising of both gamification and serious games is met with real success narratives; however, it is a novelty in South Africa.

Thirdly, the term 'decolonised education': although many scholars have firm differences with each other in opinions on this term (cf. Buthelezi 2017; Staff Writer 2019), the author has chosen to extend a definition proposed by Wingfield (2017) with Buthelezi (2017) added: Decolonised education 1.For a review article on this topic, see Laal (2011).

2.See The Chalkboard (2019) for all the advantages of playing games in the classroom - this is gamification. 
implies that the educational authorities in a country should develop a unique set of knowledge skills, values, beliefs and habits for schools and post-school institutions that are acceptable for and inherent to the people groups in that country, utilising 'the best knowledge skills, values, beliefs and habits from around the world' (Wingfield 2017).

Decolonisation in education in South Africa was incited by \#FeesMustFall protests - mostly by students - between 2015 and 2017. The students demanded a prioritisation of African studies in institutions of higher education to serve the African needs (cf. Staff Writer 2019), as well as free quality education (Buthelezi 2017). Decolonisation should not be confused with transformation, although these terms share many core elements. For many scholars, transformation in education refers to the replacement of the documents written by white or European scholars, pretending that this is decolonisation. They then use the two terms interchangeably (cf. Mgqwashu 2019). However, decolonised education is not an endeavour of one racial group over against the others, but of all academics together in a country. These academics must design courses that are 'informed by life as it is lived, experienced and understood by local inhabitants' (Cape Digital Foundation 2019). This will inspire the academic growth of real African institutions of higher education.

With the provoking heading 'The Fourth Industrial Revolution - decolonise education or die' and the discussion that follows, Cape Digital Foundation (2019) is adamant that the education system has to change in accordance and together with technology; otherwise, universities will be obsolete by 2030. ${ }^{3}$ This supports the application of gaming in curricula, as suggested in this article.

The Fourth Industrial Revolution: The world is currently experiencing the commencement of the Fourth Industrial Revolution. Schwab (2016) supplies the background leading to the current revolution:

The First Industrial Revolution used water and steam power to mechanize production. The Second used electric power to create mass production. The Third used electronics and information technology to automate production. Now a Fourth Industrial Revolution is building on the Third, the digital revolution that has been occurring since the middle of the last century. It is characterized by a fusion of technologies that is blurring the lines between the physical, digital, and biological spheres.

According to Buthelezi (2017), the 'Fourth Industrial Revolution is ... impacting all disciplines, economies and industries'. This entails a revolution in the logistics of education and is connected to and embedded in an informational environment, called the infosphere (cf. Floridi 2011:228; 2014). In this infosphere, the participants are more and more becoming 'informational organisms' called 'inforgs', interacting with other inforgs and 'smart, engineered artefacts'

3.They opt for much more practical curricula, identifying and covering the challenges 'that infrastructure, governance and sanitation. This can be achieved by identifying not infrastructure, governance and sanitation. This can be achieved by identifying not
only threats and challenges but also opportunities in industries such as agriculture, only threats and challenges but also opportunities in industries such as agricultu
resource development, art, design and culture' (Cape Digital Foundation 2019).
(Floridi 2011:232). This 'complex' situation puts pressure on educators, business entrepreneurs, students and learners, to change and adapt accordingly and in several aspects of life simultaneously. It also opens up opportunities for radical and new research and innovation that was unthinkable a few decades ago. Buthelezi (2017) adds: 'Revolutionary and unconventional teaching methods will be fundamental in innovating and carving out a new Africa', focusing specifically on critical thinking and entrepreneurship.

Lastly, the term 'paperless' has importance: the dreadful 'books of knowledge' called study guides, and the tutorial letters filled with tips for the summative examinations, in fact, belong to the previous century. All the information a student needs should be downloaded on their electronic devices. For starters, the bring your own device (BYOD) principle should be implemented. 'Device' does not really refer to a laptop or computer, but, in fact, to a tablet or smartphone. A course, whether it is 'paper behind the glass' or a real online course, must be divided in small enough files that can be opened on these devices. The dream would be to connect a serious game to each of these courses.

Higher education in the 21st century should be presented in a paperless way, not only at off-campus or distance universities, but also at residential universities (cf. footnote 1). This applies to the faculties or departments or disciplines of theology at these universities as well. As many as possible courses should be presented in an online way, with no paper used. Linked to that, the application of serious games is also imperative in theology courses, as most of the theology students, just like all their friends in other disciplines, are seriously involved with their smartphones and/or tablets - either on social media or by playing games (more about this below).

In this essay, the author focuses on undergraduate theology students who have to take the biblical languages, Greek, Hebrew and, in some cases, Latin, as compulsory subjects. These languages help students to read and study the Bible in the original languages, instead of using (one of) the myriads of translations available. To read and understand these languages is quite a challenge, and therefore the author suggests that a 'cheap' serious game be implemented to assist the students in having fun while studying these languages. This game will take the student to the 'eighth continent ${ }^{\prime 4}$ the virtual continent (also called space station or world or planet) of gaming (cf. 8c.com 2019).

If an educator wants to be really smart and (1) does not like to 'talk-and-chalk' (using chalk on a blackboard while explaining the content of a specific lesson or unit), (2) does not want to create tests or assessments on paper and (3) would like to stimulate collaboration between the students in the class, then there are many free apps available for them: 'Google Classroom [is] a free online learning platform, BookWidgets ... create[s] tests, assignments and other fun

4.In fact, it should be the ninth continent, as the most recent research has discovered that New Zealand is actually part of a hidden continent - the tip thereof - called Zealandia or 'Earth's hidden continent' (Millstein 2017). 
digital exercises and Padlet ... stimulate[s] collaboration in the classroom' (Renard 2017). Smart-board is also available, which is a 'whiteboard in a digital world', used by the educator in front of the class, being connected to every device in the class, on which any student is allowed to write from their own devices, together with the educator, while each full board can be saved as a file (Buthelezi 2017).

\section{Constructivism as learning theory}

According to constructivism, which is a learning theory, especially utilised in psychology (cf. The University of Sydney 2018), learning is an active and contextualised process in which someone constructs knowledge (cf. Concept to Classroom 2004) instead of acquiring it in a passive way (Learning Theories 2019). ${ }^{5}$ The student therefore becomes an 'active agent' in the construction of knowledge (Bada 2015:66).

This construction is based on one's personal experiences (previous knowledge) and hypotheses that one has of their environment. These hypotheses are continuously tested through a person's engagement with their surrounding environment, as they have the choice to reconcile the new knowledge with the old, or to discard it (Concept to Classroom 2004). These experiences differ from one person to the other (cf. Learning Theories 2019). Applied to the use of serious games - where the student immediately becomes an 'active agent' - the educator should encourage students to use the game, which contains knowledge unknown to them, to engage with it and test it to construct new knowledge and to master it (cf. MacLellan \& Soden 2004:254).

\section{'Educational games': Are you serious?}

This question could be understood in two ways: from a negative side, people may question the use of gaming in an educational environment, arguing that games and school or academia are incompatible: 'You either work or you play' was a pre-21st-century epistemology. From a positive side, this may invoke an expectation from a person knowing that most people or students are almost or already inforgs, someone who knows that globally many people, specifically students, are playing games on their smartphones or tablets on a daily basis (cf. Ifenthaler, Eseryel \& Ge 2012:1; NMC Horizon Report 2012:18; Oliver 2017:2 of 15 pages). Bates calls them 'digital natives' (at the hand of Prensky 2001) who are constantly 'on' (Bates 2015:34-35). This section discusses the advantages of gaming (specifically serious games) and the responsibilities of educators.

One of the prominent advantages of playing games on a device is that one can play it whenever it is convenient and wherever one wants to play. Another advantage is that when a person plays games, it helps to stimulate the production of a chemical called dopamine as well as the hormone called endorphin. Together with serotonin and oxytocin, dopamine and endorphin form the quartet of neurotransmitters that are responsible for people's happiness. It also incites learning through the reinforcement of neuronal connections (Growth Engineering 2016). Pappas argues that with the release of endorphins, a student retains more information because they experience more fun and feelings of calm and well-being (Pappas 2014a).

The receiving of rewards further results in the student associating the learning process with positive emotions, thereby wanting to learn more (Growth Engineering 2016), in this way becoming a lifelong learner. The NMC Horizon Report (2013:21; cf. also Growth Engineering 2016) indicates that educational gaming has proven 'to increase soft skills in learners, such as critical thinking, creative problem-solving, and teamwork'. Pappas (2014b) adds that gaming increases engagement as it creates challenges and instils a sense of accomplishment. Rapti (2013b:93-94; cf. Rapti 2013a:255-262) indicates that all these characteristics of gaming evoke a desire from the student with reference to status, selfexpression, competition and altruism. That desire should be implemented in serious games.

With all these characteristics in mind, the responsibility of the educator is to create the optimal learning environment for the student. A game should therefore be a 'transformative digital learning tool to support students with deep and meaningful learning' (Oliver 2017:7 of 15 pages). As the game should be designed to support content learning, it will have to make the student curious as to what-is-next and challenge the student to partake in such a way that implicit learning (where a student learns something without any conscious intent) takes place. The game must also have the ability 'to create multiple types of cognitive learning strategies for the gamer, like problem-solving' (Oliver 2017:7 of 15 pages). It should furthermore be 'active, goal-oriented, contextualized, and interesting' (Shute \& Ke 2012:47), within an interactive environment. Constant feedback is very important and should be attention grabbing, while the challenge levels should be well designed (cf. Shute \& Torres 2012:92), always with scaffolding in mind (it must not be too easy or too difficult - cf. Rosenschine \& Meister 1992:26-33). When playing the game, the student must constantly feel in control, not only of the self, but also of the game. This will increase the student's responsibility to interact even more with the game, creating a commitment for the student.

Assessment is one of the focus areas of education (cf. Loh 2012:123-144). According to Ifenthaler et al. (2012:6-7), (intelligent) assessment must take place while students are playing an educational game, also implying that the educator should always be aware of the progress of each student. Ifenthaler (2009:83-101) elaborates on this by stating that an educator must always employ multiple measurement procedures to make the assessment reliable and to give valid feedback to the students. The point here is immediate feedback, actively guiding the student on specific areas where they have difficulties (Shute \& Spector 2010). 


\section{Let's play!}

It is important to state here that everything discussed in this section is only suggestions of how a serious game should operate, as well as all the actions linked to it. The reader may use any and/or all of these suggestions and improve on it in any way they want, without the fear of transgression of copyright.

\section{Game and application (app) design}

To have a designer's design, a serious game from scratch will cost lots of money. The Internet, however, boasts with many ways in which a game can be designed 'for free'. ${ }^{6}$ First of all, a good game app should be designed. The Internet supplies us with many ways in which we can design or create a unique app 'for free', such as Apptooltester (2017) and AppsGeyser (2019). The latter website also shows us how to design an Android game 'for free'. Other websites helping us to design a game are, among many others, Flowlab Game Creator (sa.) and Buildbox (2018). Should the educator be unwilling to go this way, there are two other options left: firstly, some already existing games fit perfectly in the curriculum of specific courses, making it easy for the educator or university to come to an arrangement with the developers to use their game; secondly, there are game developers who are willing to adjust their existing game to become an educational (serious) game. The author of this article has the privilege of having a designer who already has designed two online games and who is willing to adjust one of his games to fit into a specific theological course.

The educator should take heed of the fact that this endeavour will take much time and effort, as well as convincing the institution of the real need for a serious game. The outcomes will, however, overshadow all the painstaking efforts to get a designer, get the (financial) approval of the institution, get or design a workable game and so on.

\section{The courses online}

When it comes to (foreign) languages, a student needs as much information as possible. Therefore, the choice is to put the three language courses, Greek, Hebrew and Latin on the Internet as paper behind the glass, in small enough files so that a student will be able to open it on a smartphone. The tutorial letter/s should accompany the other files on the Internet. The students will attend classes with their devices (BYOD) and should mostly look on the device (see above) as the class progresses. Each class should start with an online assessment of 5-10 min, which could also be regarded as roll call, if necessary.

\section{The game}

In this section, only one of the three languages will be used, namely, Greek, as everything said about this subject will also apply to the other two. The easiest game to design - it makes the game very easy and small enough to access and to play - is a question-and-answer game (Socratic method of teaching ${ }^{7}$ ). The question-and-answer method may sound a little dull or 'boring', but this method has proved that the kind of repetition happening while a student plays the game helps the student to retain much knowledge. Bjork calls it 'spaced repetition' which is most effective, as the student learns in short bursts right through the course and is assessed - they actually assess themselves with every game played - on a daily basis (Bjork 2012), discovering their own strong and weak points.

The welcome (introductory) screen (not shown here) of the game must already arouse the students' excitement. This is something the educator and designer should carefully discuss. It would also be good to involve a few students to get their opinions and assistance. This screen is followed by the stats screen $^{8}$ (Figure 1), indicating to the student their position and progression, as well as their awards. On the top left of the screen is the student's name or nickname (the student number will reflect on the educator's screen), and to its right is the level which this student has already reached. Levels are created on a basis from very easy to very difficult. The more the student plays, the more levels will be completed, more experience points (XPs) will be gained, and it becomes progressively more difficult as well. The time of day appears to its right.

Beneath the name is a heart, indicating the total of lives available for a student to play the game. One game equals one life (heart). However, the student can gain lives by answering all the questions of one game correctly, or by gaining a specific amount of XP per game. Every day a student received 10 hearts for free.

Sometimes, the game will give the student a freebee of $1 \mathrm{~h}$ play without taking any lives. The question mark underneath the time is an indication of the amount of hints a student has. A hint can be used when a student is uncertain of the answer to a question. When pressing the hint box, half of the answers is taken away. The student receives a total of three hints per day. The star underneath the heart is a medal awarded to the student for every 100 questions answered correctly. Every 10 stars gain an extra amount of XP. To the right of the star is a treasure chest. These chests are linked to specific difficult questions. When that question, which is not marked as a difficult question, is answered correctly (without using a hint), the treasure chest appears on the screen and is added to the total of chests. Every 10 chests gain an extra amount of XP. The trophy on the far right indicates the student's position in the class. This is an optional extra for those learners who love to compete and be informed of their position in the class. This will also motivate and challenge the student to play ('study') harder to become number 1 or part of the top 10 . Then, the XP in the middle of the screen: XP shows the student their position or degree of progression and performance on a specific level, and how far from levelling up the student is.

7.Socrates was an Athenian philosopher who lived from 469 to 399 BCE.

8.All the pictures used in this article are taken from the author's personal archive. 


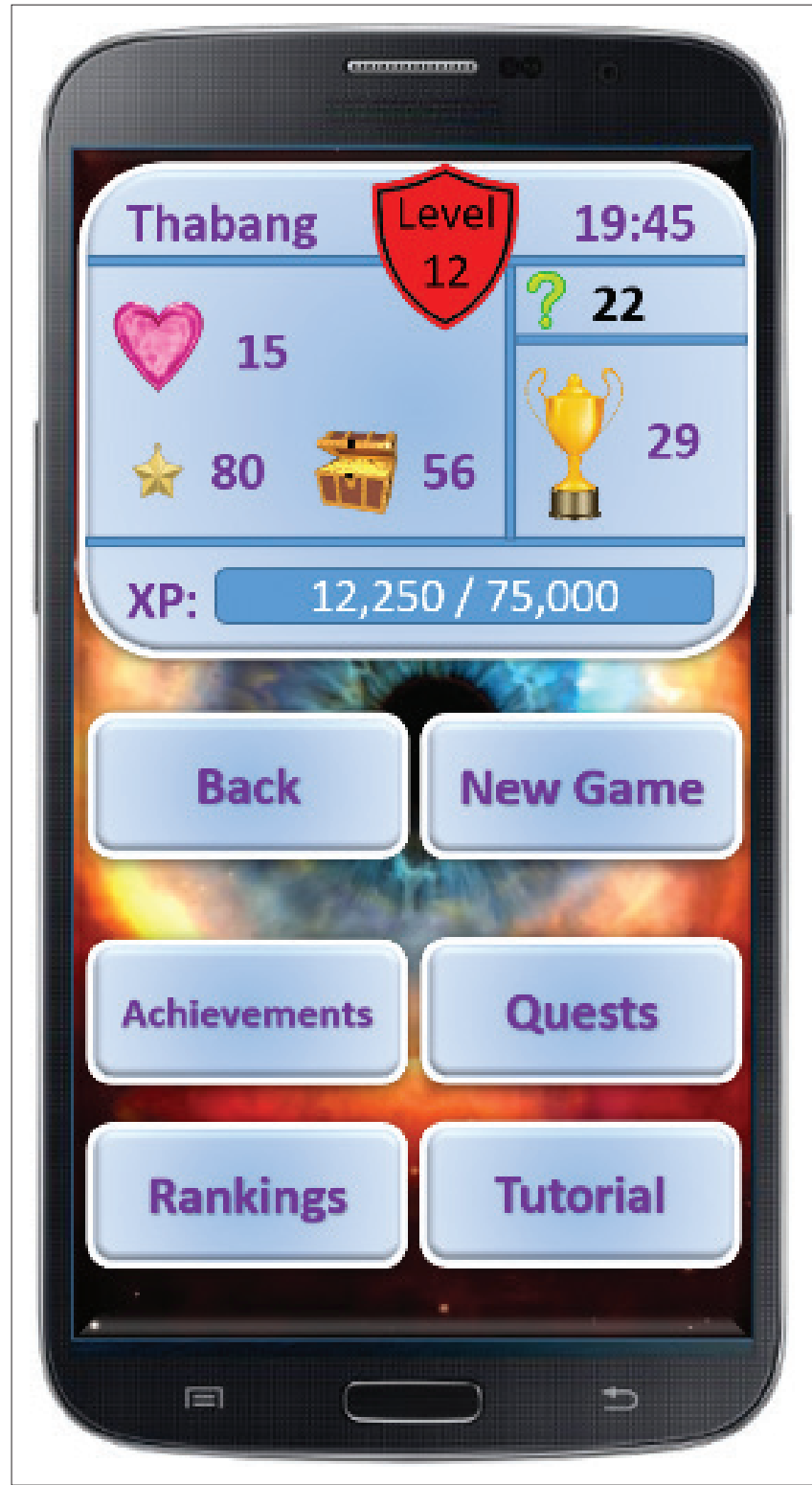

Source: Author's personal archive

FIGURE 1: Stats screen.

With reference to the bottom four tick boxes, the following is: when pressing 'Achievements', it indicates to the student what their strong or weak points are, for example, adjectives 5 , nouns 6, but verbs 1 (out of 10). The 'Quests' box links to the previous one. When a student presses this box, they can choose a specific topic (their weak point) and just get questions on that topic, for example, nouns with an o-declension. This is a real assessment activity: if the student gets $80 \%$ or more for this quest of 50 questions (three hearts used for this game), they receive a quest-star and 20000 XPs. When the 'Rankings' tick box is pressed, the student sees the report that is sent to their educator on a daily basis: how many games did the student play on that day, during the past week, the past month and the total of games being played by the student; it also indicates what the student's ranking was during each of these indicated time spans. This indicates to both the educator and the student how diligent this student is, and what progression the student has shown.

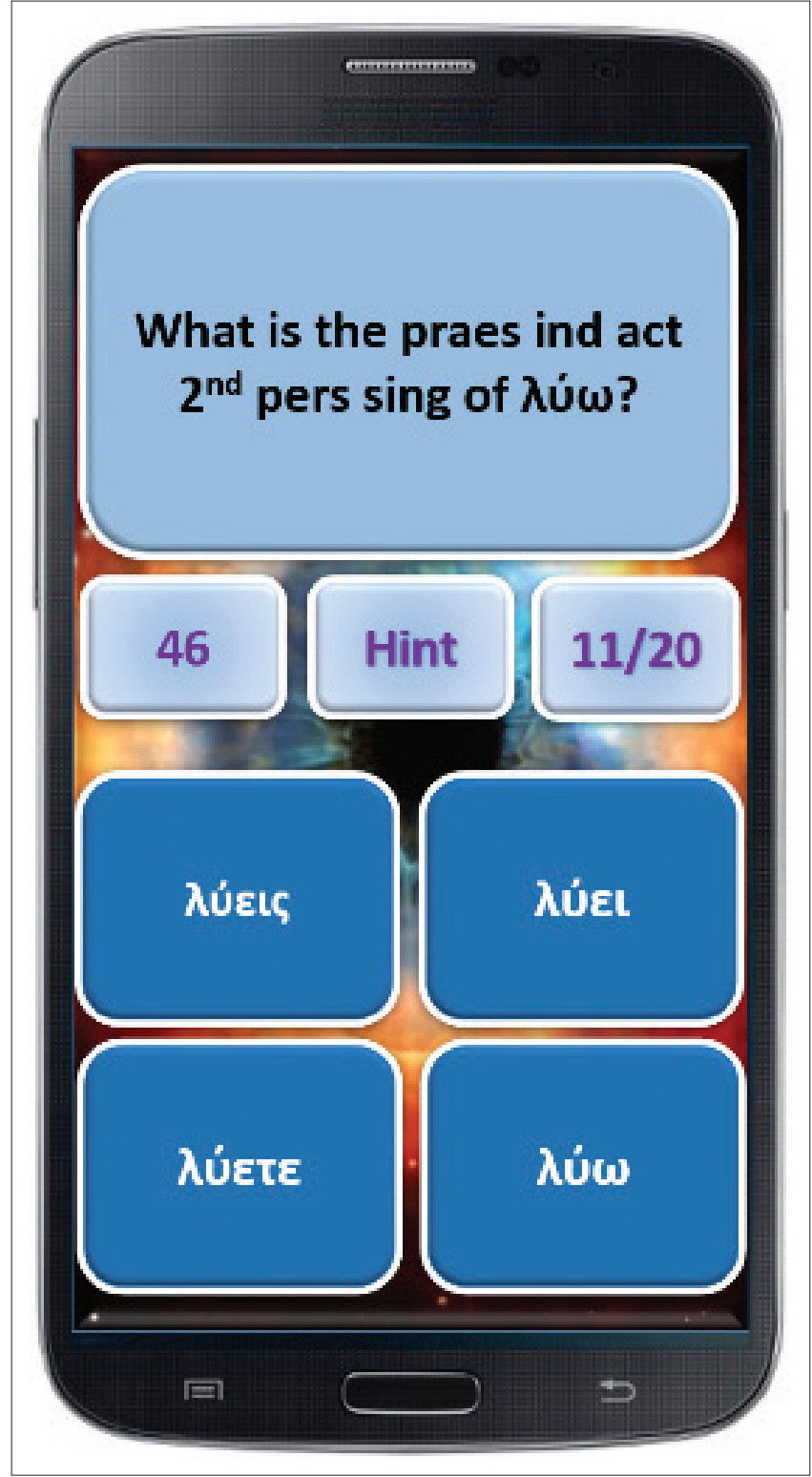

Source: Author's personal archive

FIGURE 2: Play screen.

The 'Rankings' screen also indicates the total of XPs already earned by the student. To 'complete' the game, a student must earn at least 500000 XPs. The amount of XPs earned should count as $30 \%$ of the total formative assessment marks. Should the student's XP be the best in the class, another 10\% can be added to the assessment marks, while being part of the top 10 in the class, another $5 \%$ should be added to their total.

The 'Tutorial' tick box gives the student immediate access to a specific part of the course, without exiting the game. On the communications screen (not shown here), the student has the option to contact any other student in the class, as well as the educator - per e-mail, Facebook or twitter.

The game starts on difficulty level 1, with a question and four possible answers (see play screen in Figure 2).

The content of the questions links to the lessons or modules performed up to that very day. Twenty questions are screened 
for one game to be completed. When the student has reached 25000 XPs, they move on to the next level. Every consecutive level requires more XPs before it is completed. From level 10 onwards, the options per question increase to six answers, and so progressively up to eight answers per question. The questions could be straightforward, like, What is the praes ind act 2 nd pers sing of $\lambda v \omega ?$ ?, with four possible answers (as indicated in Figure 2). Here, the educator can be very innovative and think about interesting questions or statements, also short sentences to translate. On this screen, the indicated time is on the left, showing that the student has $46 \mathrm{~s}$ left, starting at $60 \mathrm{~s}$. The student has to answer before the $60 \mathrm{~s}$ have expired. Experience point is linked to the number of seconds left after the student has correctly answered a question. The student may use a hint if needed (already discussed). The box on the right $(11 / 20)$ indicates how many questions the student has already answered.

What makes this game even more effective ('nice to play') is first that when the student gives the wrong answer, it immediately supplies the correct answer as well as the option to look it up in the online study guide; secondly, when the game is completed, there is an optional training session in which all the questions being answered wrongly are asked again, giving the student the opportunity to make sure about the answer.

Having conducted the training session and answered all the questions correctly, the student is awarded with a bonus (see Figure 3) by choosing one of the countries of Africa to see what bonus (award) is hidden behind it. After that, the student receives $\mathrm{XP}$ for the game and has the option of playing another one or opting out.

If you feel bitten on this very moment, it was not a mosquito, but the educational gaming bug that has bitten you ... Enjoy and cherish it.

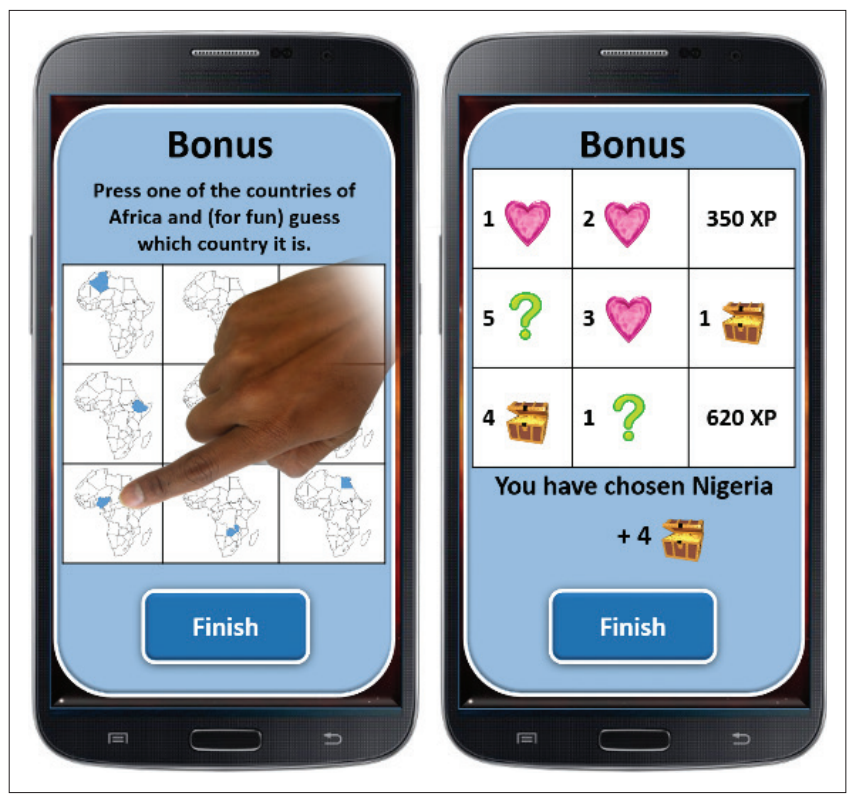

Source: Author's personal archive

FIGURE 3: Bonus time.

\section{The challenge(s)}

Nowadays, all the tools are available to create the best educational game ever for our students. There are, however, a few challenges that stand in the way of the 'best educational game': first of all, the educator must be absolutely persuaded that this game will fit into their course/s, as this is going to take much time and effort to complete. Secondly, funding is always a challenge, especially because the request for funding will have to be preceded by an extensive time of persuasion of the (older) top management. If this process is successfully completed, the educator needs a designer who knows the work, and who will be committed to complete it. If the educator has chosen an existing game, then they will have to contact the designer or owner of the game and get a quote for using the game. This should then become step 1 . After all of this is said and performed, the educator will never look back and enjoy years of joyful and productive education, well knowing that the best possible equipped students are delivered to the next stage of education, students who will most probably become lifelong learners.

\section{Conclusion}

Education in South Africa was for too long stuck in a colonised (Western) and Third Industrial Revolution education, really distant from its learners and students. Having a multiracial and multicultural student population in this country, the time has come to overcome this challenge and change to a decolonised and Fourth Industrial Revolution educational system, starting already in Grade R, covering all the educational systems in the country (cf. Floridi 2011). Gaming (serious games and gamification) is part and parcel of this revolution as it is part of the lifestyle of most of the people in our country because from childhood onwards, games are the most natural way of learning things (cf. Sung \& Hwang 2013:44), making us natural gamers. Nowadays the industry provides us with highly sophisticated instruments to play our games on and to interact with each other via gaming.

The Fourth Industrial Revolution does not require paper because everything that one needs is on the device one has be it a smartphone, tablet, laptop and so on. This revolution calls for a paperless society and effective use of technology. As most of the students are using their devices almost on a permanent basis being on social media or playing games, an educational game will not be a Fremdkörper for them but will fill their life with a meaningful engagement with the brilliant piece of technology they already have in their hands.

However, the biggest challenge that the current education system in South Africa has is unwilling or ignorant educators, with funds probably being the second biggest challenge. It is the fact that change is not always desired by every educator, especially in higher education - by younger educators who must finish their $\mathrm{PhD}$, and by older educators who are so stuck in their 'old ways' that anything new poses a threat to them - and the (older) management who should be convinced that gaming is part of the Fourth Industrial Revolution and that it needs to be implemented into decolonised education. 
To create a link between education and games is less easy but so important for the 21st century.

Optimistically, this article will motivate or persuade one educator to change their mind, resulting in thousands of students who will receive a better education, with the possibility to become lifelong learners.

\section{Acknowledgements Competing interests}

The author has declared that no competing interest exist.

\section{Author(s) contributions}

I declare that I am the sole author of this research article.

\section{Ethical consideration}

This article followed all ethical standards for a research without direct contact with human or animal subjects.

\section{Funding information}

This research received no specific grant from any agency in the public, commercial or not-for-profit sectors.

\section{Data availability statement}

Data sharing is not applicable to this article as no new data were created or analysed in this study. The pictures used in this article were created by the author.

\section{Disclaimer}

The views and opinions expressed in this article are those of the author and do not necessarily reflect the official policy or position of any affiliated agency of the author.

\section{References}

8c.com, 2019, Welcome to the 8th Continent, the space station to play the best free games online on the planet, viewed 20 February 2019, from https://www.8c.com/ play/question_answer_games/1/.

AppsGeyser, 2019, viewed 21 February 2019, from https://www.appsgeyser.com/ gamemaker/.

Apptooltester, 2017, How to make a game app, viewed 21 February 2019, from https://apptooltester.com/how-to-make-a-game-app/.

Bada, S.O., 2015, 'Constructivism learning theory: A paradigm for teaching and learning', Journal of Research \& Method in Education 5(6), 66-70.

Bates, A.W., 2015, Teaching in a digital age: Guidelines for designing teaching and learning, Tony Bates Associates Ltd, Vancouver

Bjork, R.A., 2012, Spacing improves long-term retention, YouTube, viewed 20 February 2019, from https://www.youtube.com/watch?v=TTo35X2rqls.

Buildbox, 2018, viewed 21 February 2019, from https://www.buildbox.com/makeyour-own-game/.

Buthelezi, S., 2017, 'Imagining a decolonised 21st century education', Mail and Guardian, 06 October, 2017, viewed 21 February 2019, from https://mg.co.za/ article/2017-10-06-00-imagining-a-decolonised-21st-century-education.

Cape Digital Foundation, 2019, The role of ICT in the decolonisation of South African University Curricula - Technology is the key, viewed 21 February 2019, from
http://digitalfoundation.org.za/role-of-ict-in-decolonisation-south-africanuniversity-curricula/.

Caplan, D. \& Graham, R., 2004, 'The development of online courses', in T. Anderson \& F. Elloumi (eds.), Theory and practice of online learning, pp. 245-264, Athabasca University, Athabasca.

Cole, M., John-Steiner, V., Scribner, S. \& Souberman, E. (eds.), 1979, L. S. Vygotsky: Mind in society: The development of higher psychological processes, Harvard University Press, Cambridge.
Concept to Classroom, 2004, Constructivism as a paradigm for teaching and learning, viewed 14 February 2019, from https://www.thirteen.org/edonline/concept2class/ viewed 14 February 2019 , from
constructivism/index.html.

Davis, A., 2004, 'Developing an infrastructure for online learning', in T. Anderson \& F. Elloumi (eds.), Theory and practice of online learning, pp. 97-114, Athabasca University, Athabasca.

Deterding, S., 2011, Gamification by design: Response to Zichermann, viewed 12 January 2019, from http://gamification-research.org/2011/09/gamification-bydesign-response-to-zichermann/.

Floridi, L., 2011, 'Children of the fourth revolution', Philosophy \& Technology 24(3), 227-232. https://doi.org/10.1007/s13347-011-0042-7

Floridi, L., 2014, The 4th revolution: How the infosphere is reshaping Human reality, Oxford University Press, Oxford.

Flowlab Game Creator, s.a., viewed 21 February 2019, from http://flowlab.io/.

Gamelearn, 2017, Eight examples that explain all you need to know about serious games and game-based learning, viewed 09 March 2019, from https://www.game-learn. com/all-you-need-to-know-serious-games-game-based-learning-examples/.

Growth Engineering, 2016, The neuroscience of gamification in online learning, viewed 17 February 2019, from https://www.growthengineering.co.uk/theneuroscience-of-gamification-in-online-learning/.

Ifenthaler, D., 2009, 'Model-based feedback for improving expertise and expert performance', Technology, Instruction, Cognition and Learning 7(2), 83-101. https://doi.org/10.1007/978-1-4614-3546-4

Ifenthaler, D., Eseryel, D. \& Ge, X. (eds.), 2012, Assessment in game-based learning: Foundations, innovations, and perspectives, Springer, London.

Laal, M., 2011, 'Lifelong learning: What does it mean?', Procedia - Social and Behavioral Sciences 28, 470-474. https://doi.org/10.1016/j.sbspro.2011.11.090

Learning Theories, 2019, Constructivism, viewed 24 February 2019, from https:// www.learning-theories.com/constructivism.html.

Loh, C.S., 2012, 'Information trails: In-process assessment of game-based learning', in D. Ifenthaler, D. Eseryel \& X. Ge (eds.), Assessment in game-based learning: Foundations, innovations, and perspectives, pp. 123-144, Springer, London.

MacLellan, E. \& Soden, R., 2004, 'The importance of epistemic cognition in studentcentred learning', Instructional Science 32(3), 253-268. https://doi.org/10.1023/ B:TRUC.0000024213.03972.ce

Mgqwashu, E., 2019, Universities can't decolonise the curriculum without defining it first, The Conversation, viewed 21 February 2019, from http://theconversation. com/universities-cant-decolonise-the-curriculum-without-defining-it-first-63948.

Michael, D.R. \& Chen, S.L., 2006, Serious games: Games that educate, train, and inform, Thomson Course Technology, Boston, MA.

Millstein, S., 2017, 'Earth might actually have 8 continents \& the reason why is mindboggling', bustle, viewed 12 March 2019, from https://www.bustle.com/p/earthmight-actually-have-8-continents-the-reason-why-is-mind-boggling-39344.

Ncube, S., Dube, L. \& Ngulube, P., 2014, 'E-learning readiness among academic staff in the Department of Information Science at the University of South Africa' Mediterranean Journal of Social Sciences 5(16), 357-366. https://doi.org/10.5901/ mjss.2014.v5n16p357

NMC Horizon Report, 2012, 2012 higher education edition, viewed 17 February 2019, from http://www.nmc.org/pdf/2012-horizon-report-HE.pdf.

NMC Horizon Report, 2013, 2013 higher education edition, viewed 17 February 2019 from https://www.nmc.org/pdf/2013-horizon-report-HE.pdf.

Oliver, E., 2017, 'Gamification as transformative assessment in higher education', HTS Teologiese Studies/Theological Studies 73(3), 15 pages, a4527. https://doi.org/ 10.4102/hts.v73i3.4527

Pappas, C., 2014a, Gamification in eLearning: Science and benefits, viewed 17 January 2019, from https://elearningindustry.com/science-benefits-gamification-elearning.

Pappas, C. (ed.), 2014b, How gamification reshapes learning, viewed 18 January 2019, from https://elearningindustry.com/how-gamification-reshapes-learning\#introduction.

Piaget, J., 1971, Psychology and epistemology: Towards a theory of knowledge, Grossman, New York.

Prensky, M. (ed.), 2001, Digital game-based learning, McGraw-Hill, New York.

Rapti, K., 2013a, 'Implementing alternative assessment methods through gamification', ICERI2013 Proceedings, International Conference in Open \& Distance Learning, Athens, November 18-20, 2013, pp. 255-262.

Rapti, K., 2013b, 'Increasing motivation through gamification in e-learning', Proceedings - 7th International Conference in Open \& Distance Learning, International Conference in Open \& Distance Learning, Athens, November 18-20, 2013, pp. 92-96.

Renard, L., 2017, How to create a paperless classroom with just 3 educationa apps, Bookwidgets, viewed 17 February 2019, from https://www. bookwidgets. $\mathrm{com} / \mathrm{blog} / 2017 / 09 /$ how-to-create-a-paperless-classroom-with-just-3educational-apps.

Richter, G., Raban, D.R. \& Rafaeli, S., 2015, 'Studying gamification: The effect of rewards and incentives on motivation', in T. Reiners \& L.C. Wood (eds.), Education and business, pp. 21-46, Springer International Publishing, Basel.

Rosenschine, B. \& Meister, C., 1992, 'The use of scaffolds for teaching high cognitive strategies', Educational Leadership 49(7), 26-33.

Schwab, K., 2016, The fourth industrial revolution: What it means, how to respond, World Economic Forum, viewed 16 February 2019, from https://www.weforum. org/agenda/2016/01/the-fourth-industrial-revolution-what-it-means-and-howto-respond/. 
Shute, V.J. \& Ke, F., 2012, 'Games, learning, and assessment', in D. Ifenthaler, D. Eseryel \& $X$. Ge (eds.), Assessment in game-based learning: Foundations, innovations, and perspectives, pp. 43-58, Springer, London.

Shute, V.J. \& Spector, J.M., 2010, Stealth assessment in virtual worlds, viewed 12 September 2016, from http://www.adlnet.gov/Technologies/Evaluation/Library/ AdditionalResources/LETSIWhitePapers/Shute-StealthAssessmentin VirtualWorlds.pdf.

Shute, V.J. \& Torres, R., 2012, 'Where streams converge: Using evidence-centered design to assess quest to learn', in M. Mayrath, J. Clarke-Midura \& D.H. Robinson (eds.), Technology-based assessments for 21st century skills: Theoretical and practical implications from modern research, pp. 91-204, Information Age Publishing, Charlotte, NC.

Staff Writer, 2019, Minister wants to 'decolonise' education in South Africa, viewed 21 February 2019, from https://businesstech.co.za/news/lifestyle/294654/ minister-wants-to-decolonise-education-in-south-africa/.
Sung, H.-Y. \& Hwang, G.-J., 2013, 'A collaborative game-based learning approach to improving students' learning performance in science courses', Computers \& Education 63, 43-51. https://doi.org/10.1016/j.compedu.2012.11.019

The Chalkboard, 2019, 10 benefits to playing games in the classroom, viewed 20 February 2019, from https://www.teachstarter.com/us/blog/10-benefits-playinggames-classroom-us/.

The University of Sydney, 2018, Constructivism, viewed 24 February 2019, from http://sydney.edu.au/education_social_work/learning_teaching/ict/theory/ constructivism.shtm.

Wingfield, B.D., 2017, What 'decolonised education' should and shouldn't mean, The Conversation, viewed 16 February 2019, from http://theconversation.com/whatdecolonised-education-should-and-shouldnt-mean-72597.

Zichermann, G. \& Cunningham, C., 2011, Gamification by design: Implementing game mechanics in web and mobile apps, O'Reilly Media Inc., Sebastopol, CA. 